\title{
Article \\ Combination of Thermal, Hydrometallurgical and Electrochemical Tannery Waste Treatment for Cr(III) Recovery
}

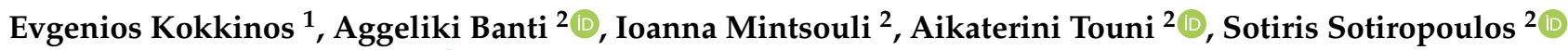 \\ and Anastasios Zouboulis ${ }^{1, *} * \mathbb{B}$ \\ 1 Laboratory of Chemical \& Environmental Technology, Department of Chemistry, Aristotle University of \\ Thessaloniki, 54124 Thessaloniki, Greece; evgenios@chem.auth.gr \\ 2 Physical Chemistry Laboratory, Department of Chemistry, Aristotle University of Thessaloniki, \\ 54124 Thessaloniki, Greece; ampantic@chem.auth.gr (A.B.); mtioanna@chem.auth.gr (I.M.); \\ aikattouni@chem.auth.gr (A.T.); eczss@chem.auth.gr (S.S.) \\ * Correspondence: zoubouli@chem.auth.gr
}

Citation: Kokkinos, E.; Banti, A.;

Mintsouli, I.; Touni, A.; Sotiropoulos,

S.; Zouboulis, A. Combination of

Thermal, Hydrometallurgical and Electrochemical Tannery Waste Treatment for Cr(III) Recovery. Appl. Sci. 2021, 11, 532. https://doi.org/ 10.3390/app11020532

Received: 17 December 2020

Accepted: 4 January 2021

Published: 7 January 2021

Publisher's Note: MDPI stays neutral with regard to jurisdictional clai$\mathrm{ms}$ in published maps and institutional affiliations.

Copyright: (C) 2021 by the authors. Licensee MDPI, Basel, Switzerland. This article is an open access article distributed under the terms and conditions of the Creative Commons Attribution (CC BY) license (https:// creativecommons.org/licenses/by/ $4.0 /)$.

\begin{abstract}
A combination of thermal $\left(500-750{ }^{\circ} \mathrm{C}\right.$ in air) and hydrometallurgical (acidic) treatments have been applied to dried tannery sludge, resulting in the initial conversion of $\mathrm{Cr}(\mathrm{III})$ to $\mathrm{Cr}(\mathrm{VI})$ and its subsequent leaching as wastewater with high $\mathrm{Cr}(\mathrm{VI})$ concentration content (3000-6000 mg/L), presenting an extraction efficiency over $90 \%$. The optimal electrochemical conditions for the subsequent $\mathrm{Cr}(\mathrm{VI})$ reduction with respect to acid concentration and acid kind were established by applying appropriate rotating disc electrode (RDE) experiments, using a glassy carbon (GC) electrode, and found to be equal or higher than $0.5 \mathrm{M} \mathrm{H}_{2} \mathrm{SO}_{4}$ (for the respective $\mathrm{Cr}$ (III) concentration range studied). The result from leaching $\mathrm{Cr}(\mathrm{VI})$ wastewater was further treated in small electrochemical bench-scale reactor for its conversion back to $\mathrm{Cr}$ (III) form, potentially reusable in the tanning industry. Ti-based anodes and a reticulated vitreous carbon (RVC) cathode were used to treat small (350-800 mL) samples in batch, as well as in batch-recirculation prototype electrochemical reactors, under the application of constant current or appropriately applied potential to achieve $\mathrm{Cr}(\mathrm{VI})$ conversion/reduction efficiency over $95 \%$.
\end{abstract}

Keywords: chromium recovery; tannery waste; hydrometallurgy; electrochemistry; $\mathrm{Cr}(\mathrm{VI})$ reduction

\section{Introduction}

Tanneries can transform raw skin into leather, by using physico-chemical and mechanical techniques. The main chemical reagents, used to produce leather with desired commercial properties, are based on $\mathrm{Cr}$ (III) salts. However, due to the low effectiveness of the aforementioned tanning processes, tanneries produce large quantities of hazardous wastewaters [1]. In order to treat this waste, several physico-chemical and biological methods can be applied, resulting in sludge production with high chromium and organic matter content. Aiming at the minimization of environmental impact, the disposal options of tannery sludge has to be considered carefully (hazardous limit is $70 \mathrm{mg} \mathrm{Cr} \mathrm{r}_{\text {total }} / \mathrm{Kg}$ ), and more sustainable management options should be promoted [2].

Following the suggestions of international environmental organizations, many researchers have studied and proposed alternative methods for the environmental sound management of tannery sludge. A specific case, generating great interest and showing certain prospects, is the application of thermal treatment, whether it concerns energy recovery [3], or as an intermediate stage of a more complex process [4]. The main feature that makes thermal treatment attractive is the great reduction in sludge volume, due to the combustion of organic matter content [5].

However, the application of increased temperatures can cause the oxidation of trivalent chromium to its highly toxic, carcinogenic and mutagenic hexavalent form $\left(\mathrm{LD}_{50}=50-150 \mathrm{mg} / \mathrm{Kg}\right)$ [6]. Simultaneously, Cr leaching can be achieved under milder 
conditions, due to the much higher solubility of hexavalent chromium. While the $\mathrm{Cr}(\mathrm{VI})$ oxyanions are very mobile (and toxic), $\mathrm{Cr}$ (III) cations are much less so and, instead, they can form the insoluble precipitate $\mathrm{Cr}(\mathrm{OH})_{3}$, which is easily separated [7]. Therefore, by reducing $\mathrm{Cr}(\mathrm{VI})$ to $\mathrm{Cr}(\mathrm{III})$ the final removal (and recovery for reuse in the tanning process) of chromium from the effluent/leachate can be achieved easily by precipitation $[8,9]$.

Several methods have been reported for the reduction of hexavalent chromium to its trivalent form in industrial wastewaters, including some originating from tanneries [10]. Chemical reduction by using $\mathrm{SO}_{2}, \mathrm{NaHSO}_{3}$ and $\mathrm{FeSO}_{4}$ as reducing agents [11,12] is a typical treatment method, which is not very satisfactory, because of the respective use of chemicals, possibly creating secondary pollution problems and large amounts of produced sludge. Biological methods, involving e.g., bacteria [13] or fungi [14], for the reduction of $\mathrm{Cr}(\mathrm{VI})$ to $\mathrm{Cr}(\mathrm{III})$ are alternatives to conventional methods; however, their efficiency is sometimes limited, since the toxic metals (including $\mathrm{Cr}$ ) can attack and destroy the membranes and the tissues of the used microbes.

The drawbacks of the previously mentioned methods can be avoided by the application of electrochemical treatment, which appears to be greener and more effective in comparison with traditional technologies. They can be applied either indirectly, such as electro-coagulation [15], which involves the dissolution of a sacrificial anode made usually of iron or aluminum [16], or directly, such as electro-reduction, in which the free electrons, supplied by a power source through an appropriate electrode, can act as the reducing agent. When the techniques of chemical reduction, electrochemical reduction (with electrogenerated $\mathrm{Fe}(\mathrm{II})$ ) and direct electro-reduction of $\mathrm{Cr}(\mathrm{VI})$ have been compared [17], it was found that the consumption of energy was higher for the case of electro-reduction. Despite this fact, direct electro-reduction has turned out to be the cleanest method, because it does not result in the contamination of sludge with iron.

In the electro-reduction technique, the cathode material is very important. Carbonbased materials such as graphite felt, fibrous carbon and reticulated vitreous carbon (RVC) [18-20] have successfully been used. Stainless steel and titanium electrodes $[17,21]$ have also been reported. RVC has been selected in most studies as the cathode material, mainly because of its higher surface area and its porous structure that creates local turbulence, improving mass transfer [22]. Although the passivation of the RVC electrode in contact with chromate ions has been reported [23], it was found elsewhere that the direct $\mathrm{Cr}(\mathrm{VI})$ reduction in both synthetic and field samples can be practically $100 \%$, by using the RVC cathode in a parallel-plate flow-by reactor and applying a relatively low voltage value [20].

Most of the aforementioned electrochemical treatment studies deal with effluents, containing relatively small amounts of $\mathrm{Cr}(\mathrm{VI})$ (typically less than $1000 \mathrm{mg} / \mathrm{L}$ ) and aim to reduce its levels below $0.5 \mathrm{mg} / \mathrm{L}$ [20], so that it can be safely discharged, according to environmental regulations. A typical application, similar to the previous conditions, is the treatment of rinse wastewaters, originating from the $\mathrm{Cr}$ plating industry. As far as we know, we are not aware of any study, dealing with the treatment of concentrated $\mathrm{Cr}(\mathrm{VI})$ solutions, such as those originating from chromium leaching from thermally treated tannery sludge by acid extraction, aiming at electrochemical $\mathrm{Cr}$ (III) regeneration and potential reuse in tanneries.

The aim of this study is to optimize and maximize the recovery of chromium from tannery sludge by a sequence of thermal, hydrometallurgical and electrochemical treatment techniques. The specific objectives have been the following: (a) the establishment of appropriate thermal treatment conditions for the quantitative oxidation of $\mathrm{Cr}(\mathrm{III})$ to $\mathrm{Cr}(\mathrm{VI})$ in the resulting solid waste; (b) the establishment of appropriate acid extraction conditions (acid kind and concentration) for the quantitative $\mathrm{Cr}(\mathrm{VI})$ leaching from the solid waste; and (c) the optimization of main experimental conditions (i.e., acid concentration, electrodes, operation of reactor) for the quantitative regeneration of $\mathrm{Cr}(\mathrm{III})$ by the application of direct electrochemical reduction of $\mathrm{Cr}(\mathrm{VI})$, using RVC electrodes in prototype batch and batch-recirculation type reactors. 


\section{Materials and Methods}

\subsection{Sample Preparation}

Reference samples were obtained from tannery air-dried sludge of the central wastewater treatment plant, serving the tannery enterprises cluster and based in the main industrial area of Thessaloniki (Sindos-Northern Greece). Prior to thermal treatment, the initial sludge was ground and sieved $(<0.5 \mathrm{~mm})$ in order to be homogenized. Afterwards, it was incinerated at the temperature range of $500-750{ }^{\circ} \mathrm{C}$ for $2 \mathrm{~h}$, in an electric furnace (model Wisd Muffle Furnaces, manufacturer Witeg, Wertheim, Germany), under the presence of air.

\subsection{Characterization}

The main structural phases of samples were identified by X-ray diffractometry (XRD), using a water-cooled Rigaku Ultima diffractometer with $\mathrm{CuKa}$ radiation, a step size of $0.05^{\circ}$ and a step time of $3 \mathrm{~s}$, operating at $40 \mathrm{kV}$ and $30 \mathrm{~mA}$. The diffraction patterns compared to the respective powder diffraction files (PDF) database [24].

Chemical analysis of the samples was conducted by the application of acid digestion, as optimized for the specific samples. Typically, $0.5 \mathrm{~g}$ of sample powder was placed in a $100 \mathrm{~mL}$ PTFE beaker with $20 \mathrm{~mL}$ of concentrated $\mathrm{HNO}_{3}$ and refluxed on a heated plate at $95{ }^{\circ} \mathrm{C}$ for $24 \mathrm{~h}$. In contrast to the common leaching procedure, this step does not apply, when the concentrated $\mathrm{HCl}$ is used as leaching agent, as in that case a significant portion of hexavalent chromium would be expected to reduce to its trivalent form. Major metal components ( $\mathrm{Cr}, \mathrm{Ca}, \mathrm{Mg}$ etc.) were determined by flame atomic absorption spectrophotometry, using a Perkin-Elmer AAnalyst 800 instrument [25], and $\mathrm{Cr}$ (VI) was measured by the standard 1,5-diphenylcarbazide colorimetric method, using a Hitachi U-2000 spectrophotometer at $540 \mathrm{~nm}$ [26]. Other parameters, such as $\mathrm{pH}$ and electrical conductivity, were determined by leaching with deionized water, at a liquid-to-solid ratio (L/S) equal to 25. The organic carbon content measured by the TOC-VCSH E200V Schimadzu Total Organic Carbon (TOC) analyzer and the inorganic carbon by the BD Inventions (model FOG L) calcimeter [27].

\subsection{Hydrometallurgical Experiments}

The leaching of chromium from the thermally treated samples was conducted according to the common hydrometallurgical protocols by examining various acidic agents. A given quantity of the solid was placed in a beaker and the leaching medium was added. The acids examined were $\mathrm{HCl}, \mathrm{HNO}_{3}$ and $\mathrm{H}_{2} \mathrm{SO}_{4}$, in the concentration range $0.05-2 \mathrm{~N}$. The rest of the experimental conditions remained constant, i.e., contact time $60 \mathrm{~min}$, temperature $25^{\circ} \mathrm{C}$ and liquid-to-solid ratio (L/S) equal to 25 . After the extraction stage, the liquid phase separated by membrane filtration under vacuum and the major metal component concentrations (namely $\mathrm{Cr}$ and $\mathrm{Ca}$ ) were determined in the filtrate.

\subsection{Electrochemical Experiments}

Preliminary electrochemical experiments, aiming to establish the appropriate acid kind and concentration for the $\mathrm{Cr}(\mathrm{VI})$ electrochemical reduction, were carried out by using a $3 \mathrm{~mm}$ diameter glassy carbon (GC) rotating disc electrode (RDE, Metrohm), in a three compartment small electrochemical cell $(200 \mathrm{~mL})$, equipped with a KCl-saturated calomel reference electrode (SCE) and a Pt-foil counter electrode. All three electrodes were placed in different compartments, separated by a lugin capillary (reference electrode) and a glass frit (counter electrode). Linear sweep voltammetry experiments (i.e., current recording when the applied potential has been varied at $10 \mathrm{mV} \cdot \mathrm{s}^{-1}$ sweep rate) were carried out with the help of an Autolab PGSTAT302N (Eco Chemie) workstation and controlled via the NOVA 1.11.2 software.

For the electrochemical treatment of $\mathrm{Cr}(\mathrm{VI})$ leachates both batch and batch-recirculation prototype reactors were used and constant current or voltage in the two-electrode setup was supplied by a DSC_ELECTRONICS, model DP60-15H, 60 V-15 A power supply. 
The batch reactor consisted of a cylindrical vessel (400 mL capacity), a $4 \mathrm{~cm} \times 3.3 \mathrm{~cm} \times$ $0.4 \mathrm{~cm}$ RVC cathode (60 ppi, Goodfellow Ltd.) and a $7.5 \mathrm{~cm} \times 3.5 \mathrm{~cm} \times 0.5 \mathrm{~cm}$ platinized Ti anode. The latter was prepared by a variation of galvanic replacement technique presented in [28], using a $5 \times 10^{-4} \mathrm{M} \mathrm{K}_{2} \mathrm{PtCl}_{6}+0.1 \mathrm{M} \mathrm{HClO}_{4}$ solution (prepared from potassium hexachloroplatinate $99 \%$ trace metals basis, Aldrich and perchloric acid 70\%, Merck). Thorough mixing was achieved via constant magnetic stirring.

For the electrochemical treatment of $800 \mathrm{~mL}$ of $\mathrm{Cr}(\mathrm{VI})$ leachate placed in a glass container, an original parallel plate-and-frame flow cell was constructed from polypropylene. The plates and the frame had a cross-sectional area of $300 \mathrm{~cm}^{2}(20 \mathrm{~cm} \times 15 \mathrm{~cm})$; the frame was $1.5 \mathrm{~cm}$ thick and its void had a hexagonal shape of a cross-sectional area of $155 \mathrm{~cm}^{2}$, resulting in a solution capacity of $232.5 \mathrm{~mL}$. The gaskets were made from PTFE (i.e., Polytetrafluoroethylene), which provided good sealing and chemical resistance. The two end-plates carry two circular stainless steel current collectors (5 cm diameter) and the entrance and exit ports for the solution $(2 \mathrm{~cm}$ diameter $)$. The stainless steel current collectors connected to the outside of cell by stainless steel threaded bars screwed into the cell. The anode was $5 \times 2.5 \mathrm{~cm}$ plate of a Metcote ES2 $\mathrm{IrO}_{2}$ anode (ICI) and the cathode an RVC foam (61 ppi, Goodfellow Ltd.). Both electrodes were attached to the current collectors by using carbon cement (WPI, Inc.). A peristaltic pump was employed to achieve a $33 \mathrm{~L} \mathrm{~h}^{-1}$ volumetric flow rate (Figure 1 ).

Samples were taken at 30 min (for the small batch reactor experiments) or at $2 \mathrm{~h}$ intervals (for the batch-recirculation reactor configuration) and the $\mathrm{Cr}$ (VI) concentration was measured by the standard 1,5-diphenylcarbazide colorimetric method (see also the previous Section 2.2).

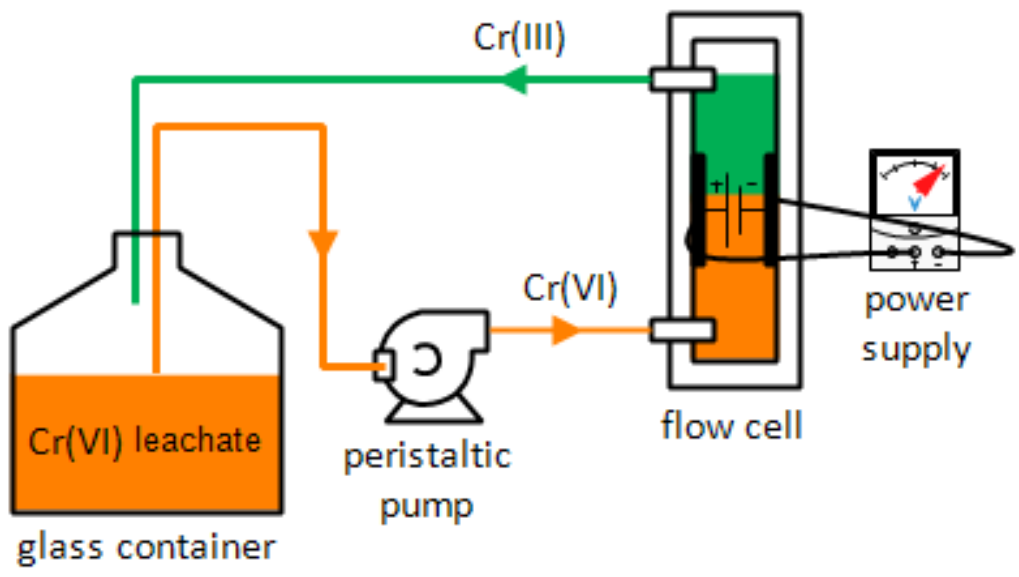

Figure 1. Flow diagram of the batch-recirculation prototype reactor experimental set-up.

\section{Results}

\subsection{Subsection Samples Characterization}

According to the X-ray diffraction (XRD) spectra (Figure 2), in all thermally treated samples, the peaks related to the presence of chromium were attributed to the hexavalent form $\mathrm{CaCrO}_{4}$ (Joint Center for Powder Diffraction Studies-JCPDS card No. 08-0458), except for the samples treated at $750{ }^{\circ} \mathrm{C}$, where the observed peaks were attributed to the trivalent form $\mathrm{MgCr}_{2} \mathrm{O}_{4}$ (JCPDS card No. 10-0351). It should be clarified that the identification of chromium's form in the initial tannery sludge was not possible, due to the amorphous structure of these samples. Instead, the crystallinity increased after the thermal treatment, resulting in the appearance of sharp peaks. The remaining peaks of these spectra present mainly the $\mathrm{CaCO}_{3}$-calcite (JCPDS card No. 47-1743) and the anhydrous $\mathrm{CaSO}_{4}$ (JCPDS card No. 37-1496). The intensity of calcite peaks decreased as the treatment temperature increased, due to its decomposition, while in the case of anhydrite $\mathrm{CaSO}_{4}$, they remain almost unaffected in the examined temperature range. 


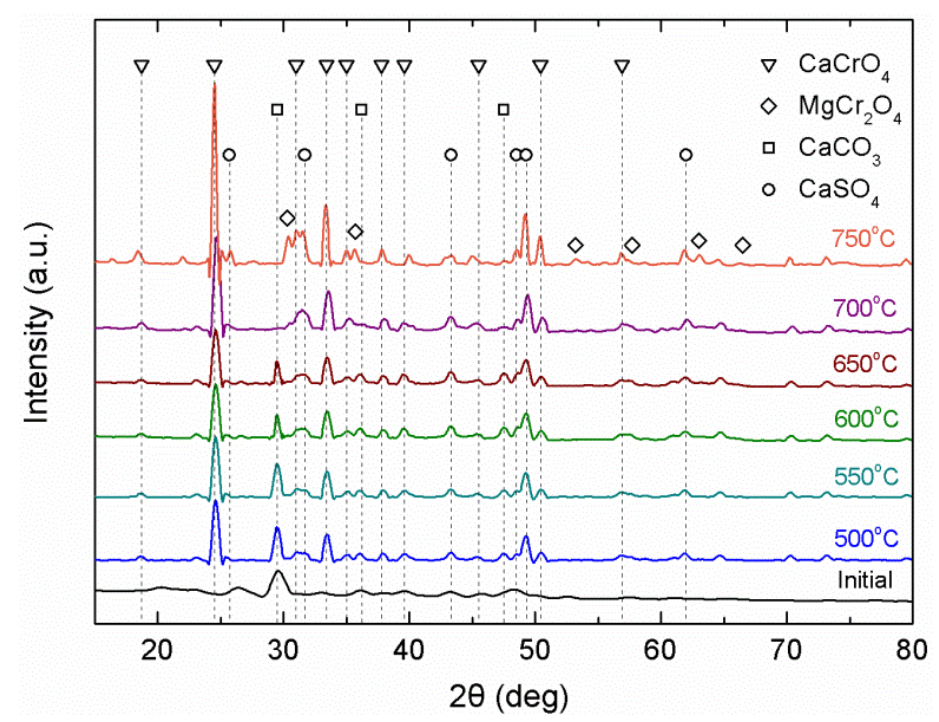

Figure 2. X-ray diffraction (XRD) diagrams of raw tannery sludge and the corresponding ashes after the application of thermal treatment.

As Table 1 shows, a significant weight loss was observed, slightly higher than $50 \%$ and almost stable, for all the examined treatment temperatures. These results can be attributed to dehydration/dehydroxylation processes, organic carbon combustion and calcium carbonate decomposition, which mainly took place at temperatures below 500 ${ }^{\circ} \mathrm{C}$. Such a weight loss led to almost doubling of metal content in the corresponding residues/ashes. Also, it was verified that the initial tannery sludge contained only $\mathrm{Cr}$ (III), whereas after the application of thermal treatment, the dominant species were $\mathrm{Cr}(\mathrm{VI})$, results which are in good agreement with the respective XRD spectra. The importance of $\mathrm{pH}$ and electrical conductivity measurements lies in the determination of appropriate equilibrium conditions during the following hydrometallurgical process, i.e., the dominant species of eluted/leached ions and their corresponding quantity, respectively. In fact, all samples (i.e., the primary waste and the resulting ashes) have been shown to be highly alkaline materials, due to the dissolution of calcium compounds. In contrast, the quantity of leached ions after combustion was substantially higher than that in the initial sludge, according also to the corresponding electrical conductivity measurements. These results can be attributed to the decomposition of organic matter, leading to the production of soluble ash constituents and, therefore, the release of more dissolved ions.

Table 1. Physico-chemical characterization of raw tannery sludge and the corresponding ashes after the application of thermal treatment.

\begin{tabular}{|c|c|c|c|c|c|c|c|}
\hline & \multicolumn{7}{|c|}{ Treatment Temperature $\left({ }^{\circ} \mathrm{C}\right)$} \\
\hline & Initial & 500 & 550 & 600 & 650 & 700 & 750 \\
\hline & \multicolumn{7}{|c|}{$\% \mathrm{w} / \mathrm{w}$} \\
\hline Weight loss & - & 52.6 & 52.8 & 53 & 54.5 & 55.4 & 55.5 \\
\hline Organic matter & 22 & 1.4 & 0.2 & 0 & 0 & 0 & 0 \\
\hline Organic carbon & 12.2 & 0.8 & 0.1 & 0 & 0 & 0 & 0 \\
\hline Inorganic carbon & 3.1 & 1.7 & 1.3 & 0.8 & 0.4 & 0.1 & 0.1 \\
\hline $\mathrm{Cr}_{\text {total }}:$ & 14.1 & 28.3 & 28.5 & 28.5 & 28.6 & 29 & 29 \\
\hline -Cr(III) & 14.1 & 6 & 5.7 & 4.5 & 3.5 & 3 & 3.2 \\
\hline$-\mathrm{Cr}(\mathrm{VI})$ & - & 22.3 & 22.8 & 24 & 25.1 & 26 & 25.8 \\
\hline
\end{tabular}


Table 1. Cont.

\begin{tabular}{|c|c|c|c|c|c|c|c|}
\hline & \multicolumn{7}{|c|}{ Treatment Temperature $\left({ }^{\circ} \mathrm{C}\right)$} \\
\hline & Initial & 500 & 550 & 600 & 650 & 700 & 750 \\
\hline & \multicolumn{7}{|c|}{$\%$ w/w } \\
\hline $\mathrm{Ca}$ & 14.8 & 28.8 & 29.1 & 29.3 & 29.7 & 29.8 & 30 \\
\hline $\mathrm{Mg}$ & 2.4 & 4.9 & 5 & 5.1 & 5.1 & 5.1 & 5.1 \\
\hline $\mathrm{Na}$ & 1.5 & 3 & 3 & 3.1 & 3.2 & 3.2 & 3.2 \\
\hline $\mathrm{Al}$ & 0.5 & 1.1 & 1.1 & 1.2 & 1.2 & 1.2 & 1.2 \\
\hline $\mathrm{Fe}$ & 0.46 & 0.5 & 0.5 & 0.5 & 0.5 & 0.6 & 0.6 \\
\hline $\mathrm{K}$ & 0.12 & 0.25 & 0.25 & 0.26 & 0.26 & 0.27 & 0.27 \\
\hline $\mathrm{Zn}$ & 0.06 & 0.14 & 0.14 & 0.14 & 0.15 & 0.16 & 0.16 \\
\hline $\mathrm{pH}$ & 9.1 & 9.2 & 9.2 & 9.2 & 9.2 & 9.2 & 9.2 \\
\hline $\begin{array}{l}\text { Conductivity } \\
(\mathrm{mS} / \mathrm{cm})\end{array}$ & 0.96 & 7.35 & 7.38 & 7.4 & 7.43 & 7.44 & 7.43 \\
\hline
\end{tabular}

\section{2. $\mathrm{Cr}$ (III) Oxidation by Thermal Treatment}

Regarding the oxidation mechanism of $\mathrm{Cr}(\mathrm{III})$, heat treatment under aerobic conditions is necessary, as in the case of pyrolysis (i.e., under anaerobic conditions) this will not take place [5]. Initially, the dominant form of $\mathrm{Cr}(\mathrm{III})$ in the raw sludge is considered to be $\mathrm{Cr}(\mathrm{OH})_{3}$, since this was precipitated from the wastewater during its primary treatment. However, through the dexydroxylation process in the temperature range $150-250{ }^{\circ} \mathrm{C}$, the requirements for the oxidation of $\mathrm{Cr}_{2} \mathrm{O}_{3}$ were fulfilled [6], according to Reaction (1). $\mathrm{Cr}$ (III) is oxidized in the presence of atmospheric oxygen, while the application of thermal/heating treatment increased both the reaction rate and efficiency [29].

$$
\begin{gathered}
2 \mathrm{Cr}_{2} \mathrm{O}_{3}+3 \mathrm{O}_{2} \rightarrow 4 \mathrm{CrO}_{3} \\
\mathrm{CaCO}_{3} \rightarrow \mathrm{CaO}+\mathrm{CO}_{2} \\
\mathrm{Cr}_{2} \mathrm{O}_{3}+2 \mathrm{CaO}+3 / 2 \mathrm{O}_{2} \rightarrow 2 \mathrm{CaCrO}_{4} \\
4 \mathrm{CaCrO}_{4}+2 \mathrm{MgO} \rightarrow 2 \mathrm{MgCr}_{2} \mathrm{O}_{4}+4 \mathrm{CaO}+3 \mathrm{O}_{2}
\end{gathered}
$$

Furthermore, the presence of other metal oxides enhances the oxidation reaction [30]. As the chemical characterization of the sample has proven, the tannery sludge contained high amounts of calcium [31]. However, the dominant form in the sludge is $\mathrm{CaCO}_{3}$ and thus, in order for Reaction (3) to proceed, a prior step is required, namely Reaction (2). The decomposition of $\mathrm{CaCO}_{3}$ was essential and became possible in the temperature range examined [4]. The combination of Reactions (2) and (3) is considered to be the dominant oxidation mechanism, since the $\mathrm{Cr}(\mathrm{VI})$ is present in the thermally treated samples as $\mathrm{CaCrO}_{4}$, according to XRD spectra. In addition, the $\mathrm{CaCO}_{3}$ content in the corresponding ashes was inversely proportional to the determined $\mathrm{Cr}(\mathrm{VI})$ percentage up to $700{ }^{\circ} \mathrm{C}$ (Figure 3). A further increase in treatment temperature (e.g., over $750{ }^{\circ} \mathrm{C}$ ) led to a partial reduction of $\mathrm{Cr}(\mathrm{VI})$ to $\mathrm{Cr}(\mathrm{II})$, since the more stable compound of $\mathrm{MgCr}_{2} \mathrm{O}_{4}$ was formed, due to the presence of $\mathrm{MgO}$, according to Reaction (4) [32]. 


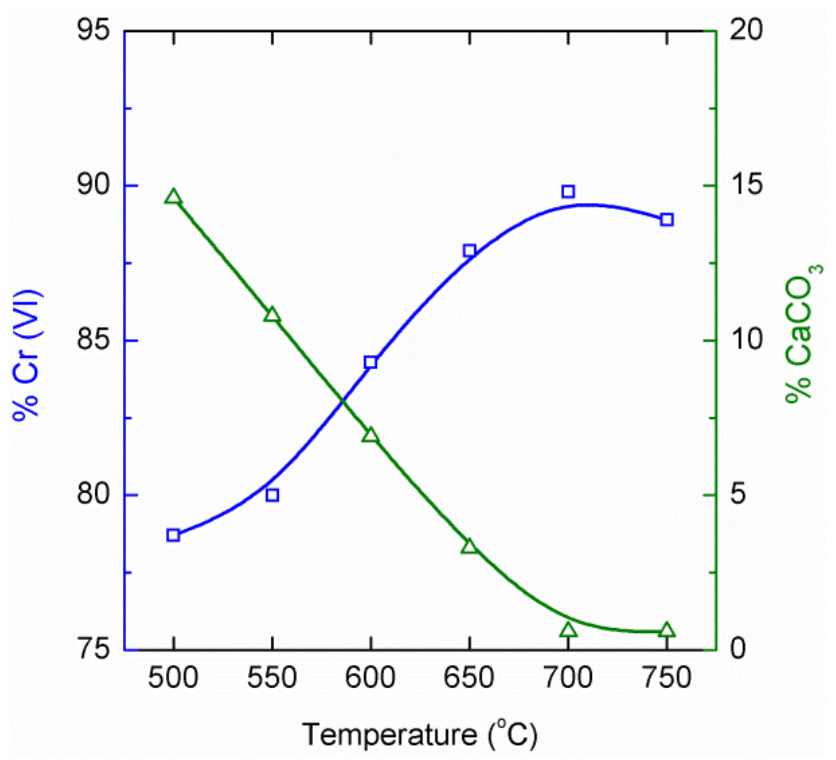

Figure 3. Correlation of $\mathrm{Cr}(\mathrm{VI})$ content with the percentage of the $\mathrm{CaCO}_{3}$ content.

\subsection{Hydrometallurgical Extraction of $\mathrm{Cr}$}

The recovery of chromium from tannery sludge ash was examined in the sample that presented the highest percentage in the metal's hexavalent form content, namely thermally treated at $700{ }^{\circ} \mathrm{C}$. As approximately $90 \%$ of total chromium content $\left(\mathrm{Cr}_{\text {total }}\right)$ existed in the $\mathrm{Cr}(\mathrm{VI})$ form, a high extraction rate was also expected. Indeed, according to Figure 4, over $90 \%$ of the $\mathrm{Cr}_{\text {total }}$ was leached, when $1 \mathrm{~N}$ of the examined acids was applied. The further increase in acid concentration presented no significant improvement in the leaching efficiency. Moreover, the L/S ratio equal to 25 proved to be suitable for extracting the majority of the initial $\mathrm{Cr}_{\text {total }}$ under the aforementioned experimental conditions, a value that directly correlated with the metal's content in the raw tannery sludge [7].

In addition, regarding the mechanism of extraction, the application of various acids causes rather insignificant differences regarding efficiency and, also, considering the standard deviation bars. This is attributed to the extremely soluble $\mathrm{Cr}(\mathrm{VI})$ species, which is the dominant form of chromium in the resulting ash. Accordingly, due to the presence of the almost insoluble $\mathrm{Cr}$ (III) form, a relative stability in the leachable $\mathrm{Cr}_{\text {total }}$ was observed for the highly acid normality values. Furthermore, the limited extraction at acids' concentration below $0.25 \mathrm{~N}$ was observed, due to its partial consumption of acid for the preliminary neutralization of alkaline ions [6]. The presence of such ions was indicated by the $\mathrm{pH}$ and electrical conductivity measurements.

By contrast, the leaching by acids presented notable variations, regarding Ca extraction (Figure 4). Considering the selectivity of this process, its leachability of Ca was also investigated, since it was proved from the chemical characterization of the samples that the tannery sludge ashes contained high levels of $\mathrm{Ca}$, equal to those of $\mathrm{Cr}$. When $\mathrm{H}_{2} \mathrm{SO}_{4}$ was employed, Ca formed the insoluble in acidic media $\mathrm{CaSO}_{4}$ compound and therefore, less Ca was transferred to the leaching solution [33]. Moreover, the $\mathrm{CaSO}_{4}$ formation was proportional to acid normality and, thus, for concentrations above $1 \mathrm{~N} \mathrm{Ca}$ extraction was minimized. Instead, both $\mathrm{HNO}_{3}$ and $\mathrm{HCl}$ proved capable to extract most of the Ca content, while the difference between them was attributed to the slightly higher solubility of the respective metal nitrate salt [34]. 


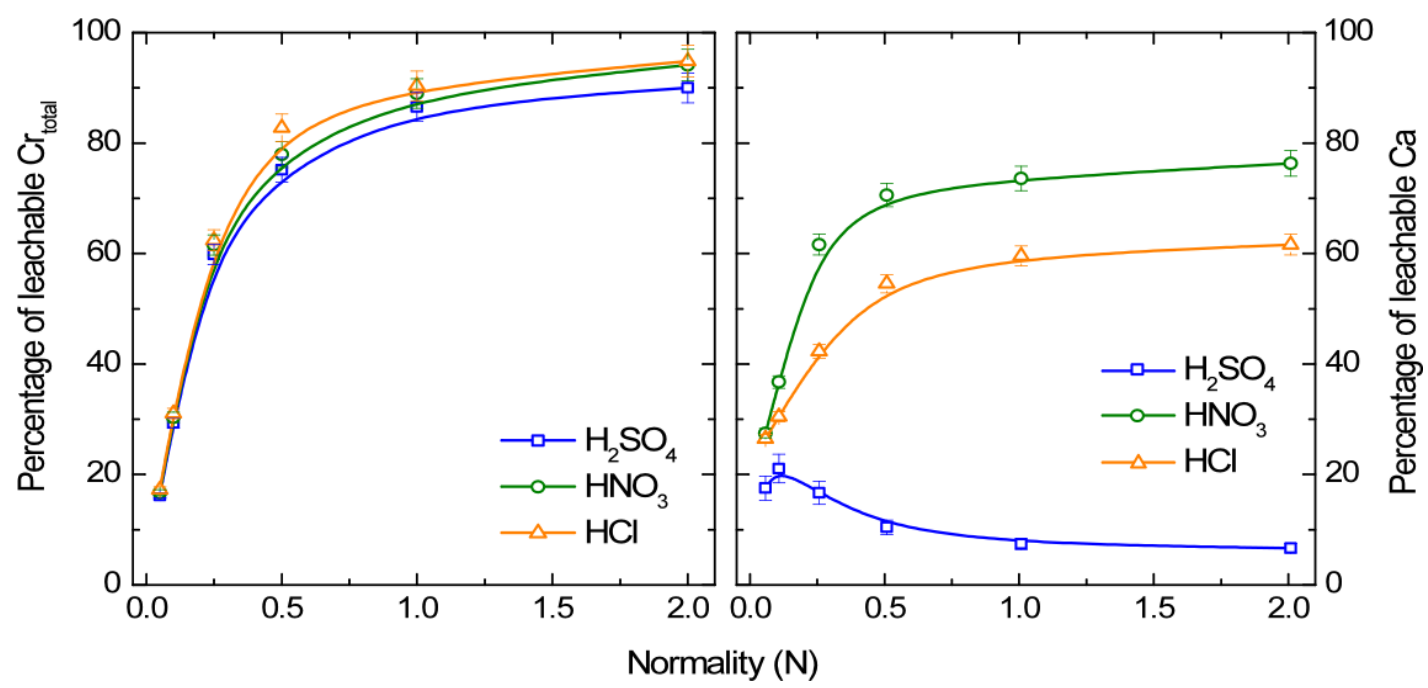

Figure 4. $\mathrm{Cr}_{\text {total }}$ and Ca extraction from the thermally treated tannery sludge at $700{ }^{\circ} \mathrm{C}$, using different common acids, applied in different (initial) concentrations.

\subsection{Electrochemical Reduction of $\mathrm{Cr}(V I)$}

\subsubsection{Exploratory Voltammetry Using a Glassy Carbon Rotating Disc Electrode}

Figure 5 presents the linear sweep voltamograms (LSVs; current vs. potential curves recorded as the potential is varied at a $10 \mathrm{mV} \cdot \mathrm{s}^{-1}$ potential scan rate), obtained with the use of a GC RDE (at a $200 \mathrm{rpm}$ rotation speed) in a solution containing $0.05 \mathrm{M} \mathrm{K}_{2} \mathrm{Cr}_{2} \mathrm{O}_{7}$ in the presence of either $0.5 \mathrm{M} \mathrm{HCl}$ or $0.25 \mathrm{M} \mathrm{H}_{2} \mathrm{SO}_{4}$. Since $\mathrm{Cr}(\mathrm{VI})$ at $\mathrm{pH}<1$ is known to exist mainly in its $\mathrm{HCrO}_{4}{ }^{-}$form [35], the negative currents correspond to the following electrochemical Reaction (5) [36].

$$
\mathrm{HCrO}_{4}^{-}+7 \mathrm{H}^{+}+3 \mathrm{e}^{-} \rightarrow \mathrm{Cr}^{3+}+4 \mathrm{H}_{2} \mathrm{O}
$$

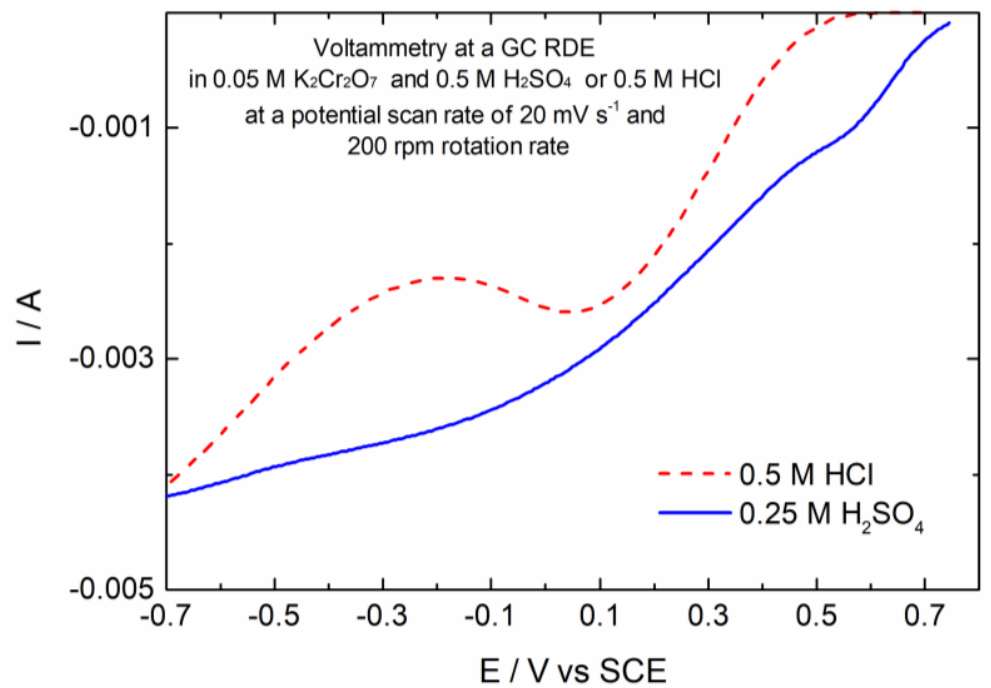

Figure 5. Current vs. potential linear sweep voltamogram (LSV) curves, recorded with the use of a glassy carbon (GC) rotating disc electrode (RDE) at a $200 \mathrm{rpm}$ rotation speed and a $20 \mathrm{mV} \cdot \mathrm{s}^{-1}$ potential scan rate, in $0.05 \mathrm{M} \mathrm{K}_{2} \mathrm{Cr}_{2} \mathrm{O}_{7}$ solutions, containing $0.5 \mathrm{M} \mathrm{HCl}$ or $0.25 \mathrm{M} \mathrm{H}_{2} \mathrm{SO}_{4}$. 
Both LSV curves coincide at similar currents of ca. $4 \mathrm{~mA}$ at the most negative potential applied $(-0.70 \mathrm{~V}$ vs. SCE), where electrode kinetics are expected to be fast and the current controlled by mass transfer. However, they differ significantly in terms of their current onset potential and shape (at the lower negative potentials in the mixed/kinetic control regime). In the presence of $\mathrm{Cl}^{-}$ions, the onset potential is more negative and there is also a significant current decrease at ca. $-0.20 \mathrm{~V}$ vs. SCE. Note also that a similar difference between $\mathrm{HCl}$ and $\mathrm{H}_{2} \mathrm{SO}_{4}$ has been reported for the $\mathrm{Cr}(\mathrm{VI})$ reduction by using an $\mathrm{Au}$ electrode [37]. The adverse effect of $\mathrm{HCl}$ acid on $\mathrm{HCrO}_{4}{ }^{-}$reduction may be due to the stronger $\mathrm{Cl}^{-}$anion adsorption on carbon [38] (i.e., competitive to $\mathrm{HCrO}_{4}^{-}$adsorption), as well as to the low solubility of $\mathrm{CrCl}_{3}$, which may precipitate on the electrode surface, produced after the $\mathrm{Cr}(\mathrm{III})$ reaction with $\mathrm{Cl}^{-}$ions.

Having established that $\mathrm{H}_{2} \mathrm{SO}_{4}$ is the best selection for the electrochemical treatment of $\mathrm{Cr}(\mathrm{VI})$ solutions, the optimal acid concentration should be subsequently identified. Figure 6 presents the LSV curves obtained with the GC RDE (at $1600 \mathrm{rpm}$ ) in $0.05 \mathrm{M}$ $\mathrm{K}_{2} \mathrm{Cr}_{2} \mathrm{O}_{7}$ solutions of different sulfuric acid concentrations in the 0.05-1 $\mathrm{M}$ range. For acid concentrations below $0.5 \mathrm{M} \mathrm{H}_{2} \mathrm{SO}_{4}$ (i.e., with $1 \mathrm{M}$ of protons available for reaction), there is a strong effect of acidity on the $\mathrm{Cr}$ (III) reduction currents. This is to be expected since, according to Reaction (5), seven protons take part in the electro-reduction of one $\mathrm{Cr}$-containing specie; hence $0.05 \mathrm{M} \mathrm{K}_{2} \mathrm{Cr}_{2} \mathrm{O}_{7}$ require a minimum of $2 \times 0.05 \times 7=0.7 \mathrm{M}$ of protons.

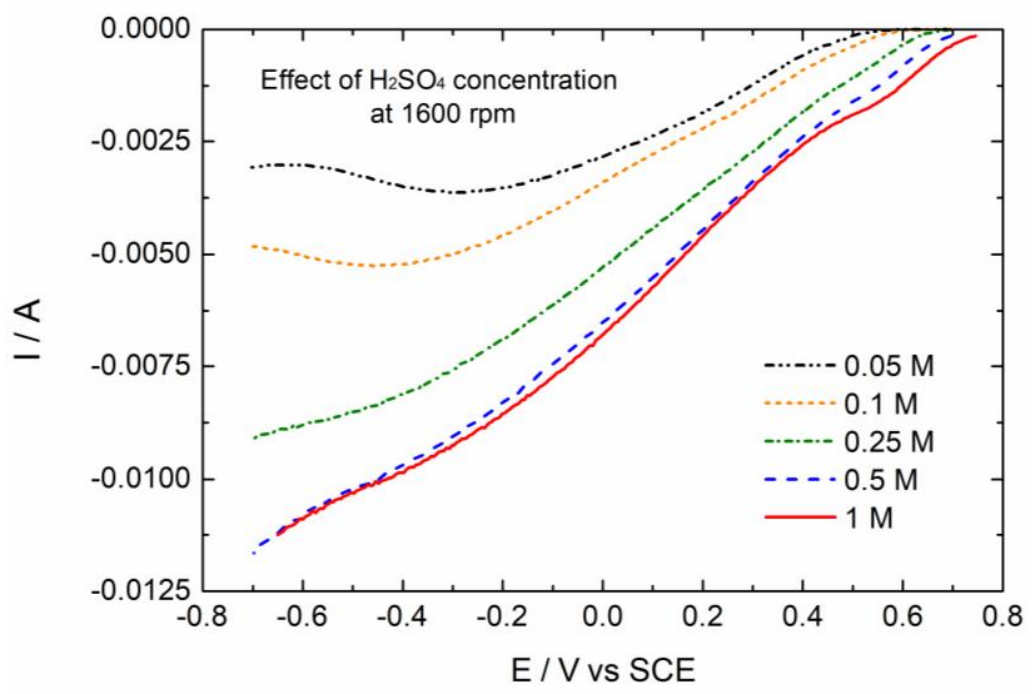

Figure 6. Current vs. potential LSV curves, recorded with a GC RDE electrode at 1600 rpm rotation speed and $20 \mathrm{mV} \cdot \mathrm{s}^{-1}$ potential scan rate, in $0.05 \mathrm{M} \mathrm{K}_{2} \mathrm{Cr}_{2} \mathrm{O}_{7}$ solutions of varied $\mathrm{H}_{2} \mathrm{SO}_{4}$ concentrations.

Finally, Figure 7 presents the effect of rotation rate (mass transfer) conditions in $0.05 \mathrm{M}$ $\mathrm{K}_{2} \mathrm{Cr}_{2} \mathrm{O}_{7}+0.5 \mathrm{M} \mathrm{H}_{2} \mathrm{SO}_{4}$ solution at rotation rates (f) in the 200-2500 rpm range. It can be observed that the current at potentials more negative than ca. $0.60 \mathrm{~V}$ increases with the rotation speed, indicating mass transfer control (partial or complete); by contrast, the ill-defined wave at the foot of the curve (in the ca. $0.70-0.60 \mathrm{~V}$ range) remains largely unaffected, further confirming that it corresponds to a $\mathrm{HCrO}_{4}{ }^{-}$adsorption pre-wave. Considering, also, the area $\mathrm{A}=0.07065 \mathrm{~cm}^{2}$, maximum reduction currents are in the $70-190 \mathrm{~mA} \cdot \mathrm{cm}^{-2}$ range. 


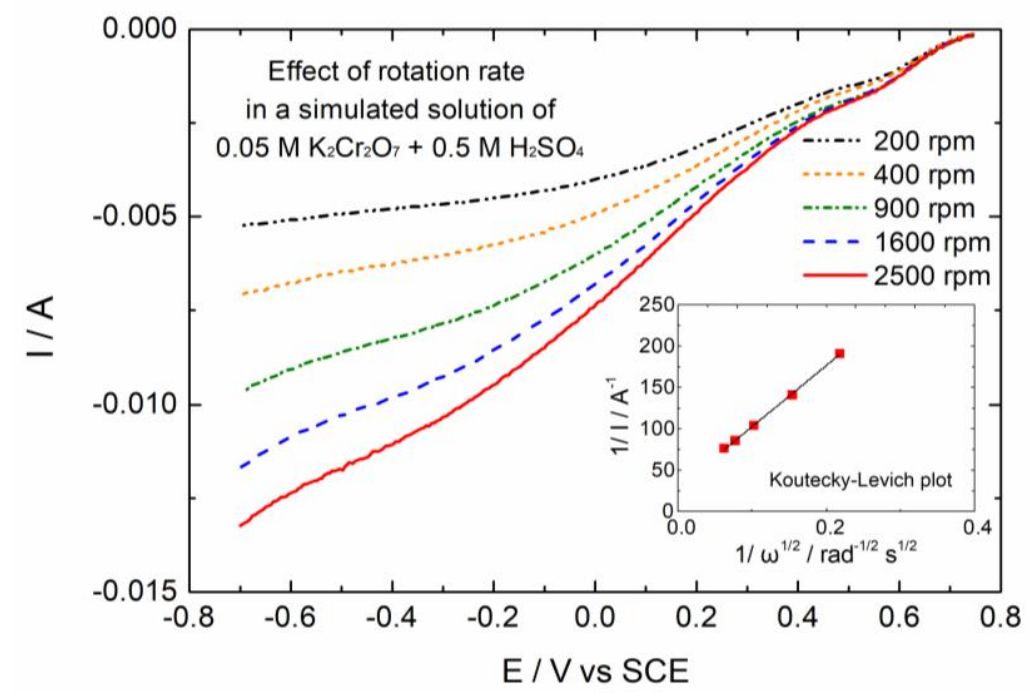

Figure 7. Current vs. potential LSV curves, recorded with GC RDE electrode at various rotation speeds (in the $200-2500 \mathrm{rpm}$ range) and a $20 \mathrm{mV} \cdot \mathrm{s}^{-1}$ potential scan rate, in a $0.05 \mathrm{M} \mathrm{K}_{2} \mathrm{Cr}_{2} \mathrm{O}_{7}+0.5$ $\mathrm{M} \mathrm{H}_{2} \mathrm{SO}_{4}$ solution. Inset: Koyecky-Levich plot for currents at $-0.6 \mathrm{~V}$ vs. KCl-saturated calomel reference electrode (SCE).

The Inset shows the corresponding Koutecky-Levich plot [39] (i.e., $1 / \mathrm{I}$ vs. $1 / \omega^{1 / 2}$, where $\omega=2 \pi \mathrm{f}$ the rotational velocity in $\mathrm{rads}^{-1}$ ) for the currents recorded at $-0.6 \mathrm{~V}$ vs. SCE.

$$
\frac{1}{\mathrm{I}}=\frac{1}{\mathrm{I}_{\mathrm{kin}}}+\frac{1}{0.62 \mathrm{nFACD} \mathrm{D}^{\frac{2}{3}} \omega^{\frac{1}{2}} v^{-\frac{1}{6}}}
$$

Equation (6) gives the reciprocal of the total current measured as the sum of two contributions, i.e., a kinetic (the first term, $\mathrm{I}_{\text {kin }}$ ) and a mass transport (the second term). From the slope of the inset of Figure 6, assuming the number of electrons $\mathrm{n}=3$ (according to Reaction (5)), and taking $\mathrm{F}=96453 \mathrm{C} \cdot \mathrm{mol}^{-1}$, the electrode area $\mathrm{A}=0.07065 \mathrm{~cm}^{2}$, the $\mathrm{Cr}(\mathrm{VI})$ concentration $\mathrm{C}=2 \times 0.05=0.1 \mathrm{M}=0.0001 \mathrm{~mol} \mathrm{~cm}^{-3}$ ) and a typical aqueous solution kinematic viscosity $v=0.011 \mathrm{~cm}^{2} \cdot \mathrm{s}^{-1}$, then the value of $\mathrm{D}=1.13 \times 10^{-5} \mathrm{~cm}^{2} \cdot \mathrm{s}^{-1}$ can be obtained for the diffusion coefficient of $\mathrm{HCrO}_{4}{ }^{-}$, which is almost identical to that reported in [20] and references therein. The validity of Equation (6) for $n=3$ is considered as a definitive proof that Reaction (5) takes place quantitatively for sulfuric acid concentrations equal or higher than $0.5 \mathrm{M}$.

\subsubsection{Reticulated Vitreous Carbon (RVC)}

Figure 8 presents the results of application constant current electrolysis for $350 \mathrm{~mL}$ samples of leachate, containing 5.9 or $3.5 \mathrm{~g} \mathrm{Cr}(\mathrm{VI}) \cdot \mathrm{L}^{-1}$ in $0.5 \mathrm{M} \mathrm{H}_{2} \mathrm{SO}_{4}$, in a small batch reactor under vigorous magnetic stirring. The applied current was $0.5 \mathrm{~A}$ which, given the real area of the RVC electrode (see the experimental section), corresponds to a cathode current density of ca. $2.4 \mathrm{~mA} \cdot \mathrm{cm}^{-2}$. The near-linearity of the $C$ vs. $t$ curves implies zero order kinetics. There are three kinetic regimes for the electro-reduction of $\mathrm{Cr}(\mathrm{VI})$, i.e., (a) the adsorption of $\mathrm{HCrO}_{4}{ }^{-}$(see also the aforementioned discussion of RDE experiments), (b) the electron transfer, and (c) the mass transport. The last two cases are both characterized by 1st-order heterogeneous kinetics. The first one provided that a full monolayer of strongly adsorbed $\mathrm{HCrO}_{4}{ }^{-}$is readily formed over a wide concentration range; thus, leading to reactant surface saturation, potentially resulting in reaction rate independent of concentration. This is also implied by the fact that the current efficiency of the process (defined as the charge consumed for $\mathrm{Cr}(\mathrm{VI})$ reduction-based on Faraday's law-divided by the total charge passed) was estimated as $104 \%$ and $108 \%$ for the two samples. This indicates that, despite the continuous decrease in bulk concentration, the steady-state reduction of a continuously replenished adsorbed layer was able to sustain the applied 
current. Noting also that $\mathrm{Cr}(\mathrm{VI})$ was converted to $\mathrm{Cr}(\mathrm{III})$ by $97.5 \%$ in $6 \mathrm{~h}$ (for $5.9 \mathrm{~g} \mathrm{Cr}(\mathrm{VI}) \cdot \mathrm{L}^{-1}$ initial concentration and by $89.8 \%$ in $3 \mathrm{~h}$ for $3.5 \mathrm{~g} \mathrm{Cr}(\mathrm{VI}) \cdot \mathrm{L}^{-1}$ initial concentration).

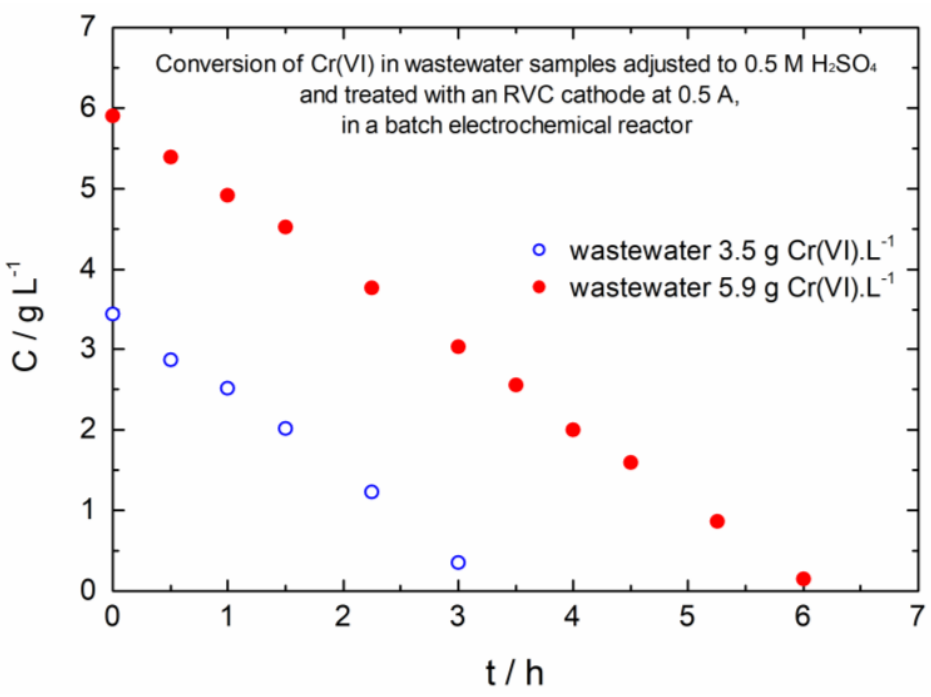

Figure 8. Concentration of $\mathrm{Cr}(\mathrm{VI})$ vs. time (h) plots during the electrolysis of $350 \mathrm{~mL}$ wastewater samples in a batch reactor, using a reticulated vitreous carbon (RVC) cathode electrode and a constant current of $0.5 \mathrm{~A}$.

Figure 9 presents the results of constant current electrolysis for $800 \mathrm{~mL}$ sample of leachate, containing $5.1 \mathrm{~g} \mathrm{Cr}(\mathrm{VI}) \cdot \mathrm{L}^{-1}$ in $0.5 \mathrm{M} \mathrm{H}_{2} \mathrm{SO}_{4}$ in the batch-recirculation reactor arrangement, described in the experimental section. The applied current was $0.5 \mathrm{~A}$ which, given the real area of RVC electrode embedded in the plate-and-frame electrochemical cell, corresponds to a cathode current density of ca. $1.25 \mathrm{~mA} \cdot \mathrm{cm}^{-2}$. The shape of the concentration vs. time curves points now to more complicated kinetics (as a plot of $\ln C / C_{o}$ was not found linear). At the relatively lower flow rates used $\left(33 \mathrm{~L} \cdot \mathrm{min}^{-1}\right)$, the mass transport limitations are likely to prevail. This is also in line with the overall current efficiency of the process, which is now estimated as only $35 \%$. As the concentration of $\mathrm{Cr}(\mathrm{VI})$ in the bulk solution decreases and the mass transport is not sufficient to sustain a full monolayer of adsorbed $\mathrm{HCrO}_{4}{ }^{-}$, a competitive reduction process (based on dissolved oxygen reduction, or hydrogen evolution) becomes operative to keep the current constant. The conversion of the $\mathrm{Cr}(\mathrm{VI})$ contained in $800 \mathrm{~mL}$ of a $5.1 \mathrm{~g} \mathrm{Cr}(\mathrm{VI}) \cdot \mathrm{L}^{-1}$ wastewater was $99.8 \%$ in $36 \mathrm{~h}$.

In order to improve the current efficiency, the batch-recirculation reactor was also operated at constant potential, by selecting the applied potential to be in the range of potentials as recorded during the constant current operation; hence, the value of $3 \mathrm{~V}$ was selected. Figure 10 presents the results of constant potential electrolysis at $3 \mathrm{~V}$ of an $800 \mathrm{~mL}$ sample of leachate, containing $4.1 \mathrm{~g} \mathrm{Cr}(\mathrm{VI}) \cdot \mathrm{L}^{-1}$ in $0.5 \mathrm{M} \mathrm{H}_{2} \mathrm{SO}_{4}$. The shape of the concentration vs. time curves points again to complicated kinetics (as a plot of $\operatorname{lnC} / \mathrm{C}_{\mathrm{o}}$ was not found to be linear). The recorded current started from values at ca. $0.5 \mathrm{~A}$ and decreases to less than $0.1 \mathrm{~A}$ in $24 \mathrm{~h}$, as expected for a current depending on the concentration of $\mathrm{Cr}(\mathrm{VI})$ in the bulk solution, which has been decreasing. Integrating the I vs. $t$ curve (not shown here) a current efficiency of $63 \%$ was estimated. The conversion of $\mathrm{Cr}(\mathrm{VI})$ from $800 \mathrm{~mL}$ leachate sample, containing $4.1 \mathrm{~g} \cdot \mathrm{L}^{-1} \mathrm{Cr}(\mathrm{VI})$, was $99.7 \%$ in $24 \mathrm{~h}$. 


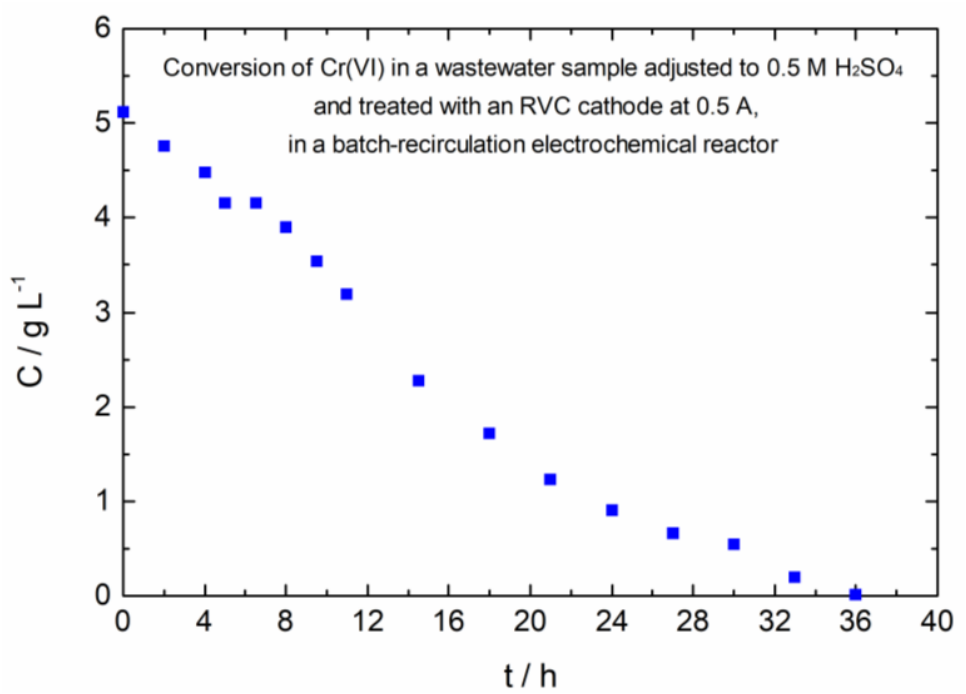

Figure 9. Concentration of $\mathrm{Cr}(\mathrm{VI})$ vs. time plots during the electrolysis of a $5.1 \mathrm{~g} \cdot \mathrm{L}^{-1}$ leachate samples in a batch-recirculation type reactor, treating $800 \mathrm{~mL}$ with a $33 \mathrm{~L} \cdot \mathrm{h}^{-1}$ flow rate, using an $\mathrm{RVC}$ cathode electrode and a constant current of $0.5 \mathrm{~A}$.

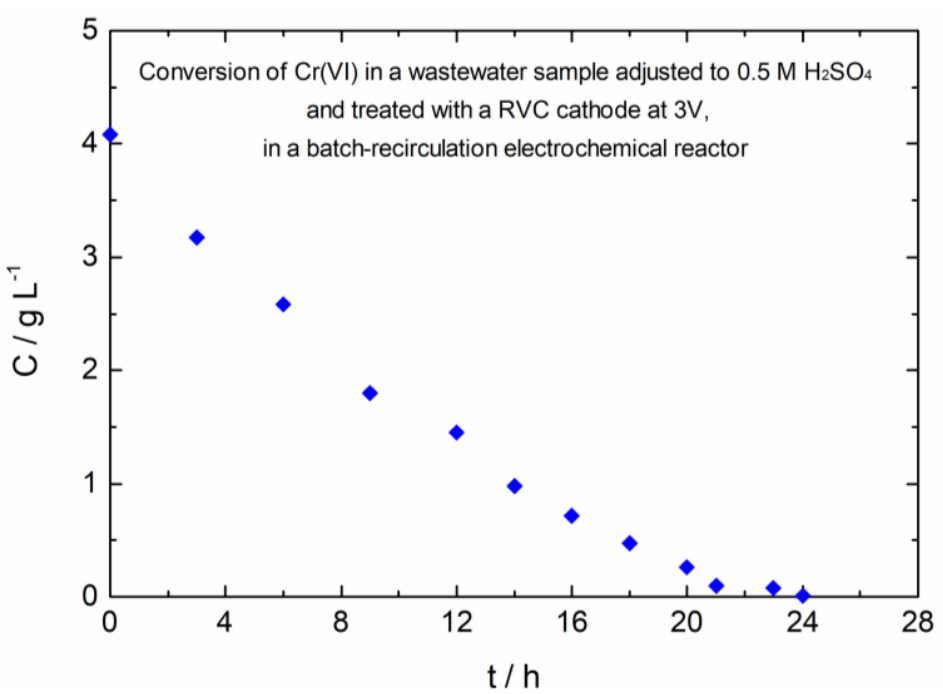

Figure 10. Concentration of $\mathrm{Cr}(\mathrm{VI})$ vs. time plots during the electrolysis of $4.1 \mathrm{~g} \cdot \mathrm{L}^{-1}, 800 \mathrm{~mL}$ leachate samples in a batch-recirculation type reactor with a $33 \mathrm{~L} \cdot \mathrm{h}^{-1}$ flow rate, using an RVC cathode electrode and a constant potential of $3 \mathrm{~V}$.

\section{Conclusions}

In this study it has been proven that by combining various procedures and exploiting their advantages, it is possible to develop a high-efficiency chromium recovery methodology from tannery sludge. As a first step, the application of thermal treatment can reduce the volume of waste almost by half, albeit oxidizing also the initially present $\mathrm{Cr}$ (III) to its toxic $\mathrm{Cr}(\mathrm{VI})$ hexavalent form. However, by applying a simple hydrometallurgical acid treatment in the resulting ashes, over $90 \%$ of the total $\mathrm{Cr}$ content can be extracted, due to $\mathrm{Cr}(\mathrm{VI})$ high solubility (the process also being highly selective). Finally, the electrochemical treatment using porous carbon cathodes (RVC), under appropriate sulfuric acid concentration and applied current/potential conditions, can result in a $\mathrm{Cr}(\mathrm{VI})$-to- $\mathrm{Cr}(\mathrm{III})$ conversion (reduction) above $95 \%$. The presented methodology highlights the benefits of the circular economy, both environmental and economical, as chromium circulates in a tannery-based route, through its recovery, with minimum losses. As future research, according to the present work, we recommend the clarification of other ions' effect, contained in the leachate, 
on the electrochemical treatment and the suitability of reusing the recovered chromium in tanning process.

Author Contributions: Conceptualization, A.Z. and S.S.; methodology, E.K. and S.S.; software, E.K.; validation, A.Z., S.S. and E.K.; formal analysis, E.K.; investigation, E.K., A.B., I.M. and A.T.; resources, A.Z. and S.S.; data curation, E.K., A.B., I.M. and A.T.; writing-original draft preparation, A.Z., S.S., E.K., A.B., I.M. and A.T.; writing—review and editing, A.Z., S.S. and E.K.; visualization, E.K.; supervision, A.Z. and S.S.; project administration, A.Z.; funding acquisition, A.Z. All authors have read and agreed to the published version of the manuscript.

Funding: This research was funded by the project "INVALOR: Research Infrastructure for Waste Valorization and Sustainable Management" (MIS 5002495) which is implemented under the Action "Reinforcement of the Research and Innovation Infrastructure", funded by the Operational Program "Competitiveness, Entrepreneurship and Innovation" (NSRF 2014-2020) and co-financed by Greece and the European Union (European Regional Development Fund).

Institutional Review Board Statement: Not applicable.

Informed Consent Statement: Not applicable.

Conflicts of Interest: The authors declare no conflict of interest.

\section{References}

1. Basegio, T.; Berutti, F.; Bernardes, A.; Bergmann, C.P. Environmental and technical aspects of the utilisation of tannery sludge as a raw material for clay products. J. Eur. Ceram. Soc. 2002, 22, 2251-2259. [CrossRef]

2. European Union. Commission Implementing Decision of 11 February 2013 Establishing the Best Available Techniques (BAT) Conclusions under Directive 2010/75/EU of the European Parliament and of the Council on Industrial Emissions for the Tanning of Hides and Skins; 2013/84/EU; European Union: Brussels, Belgium, 2013; Available online: http://data.europa.eu/eli/dec_impl/2013/84/oj (accessed on 7 January 2021).

3. Abbas, N.; Jamil, N.; Hussain, N. Assessment of key parameters in tannery sludge management: A prerequisite for energy recovery. Energy Sources Part A Recover. Util. Environ. Eff. 2016, 38, 2656-2663. [CrossRef]

4. Tahiri, S.; Albizane, A.; Messaoudi, A.; Azzi, M.; Bennazha, J.; Younssi, S.A.; Bouhria, M. Thermal behaviour of chrome shavings and of sludges recovered after digestion of tanned solid wastes with calcium hydroxide. Waste Manag. 2007, 27, 89-95. [CrossRef] [PubMed]

5. Kavouras, P.; Pantazopoulou, E.; Varitis, S.; Vourlias, G.; Chrissafis, K.; Dimitrakopulos, G.P.; Mitrakas, M.; Zouboulis, A.I.; Karakostas, T.; Xenidis, A. Incineration of tannery sludge under oxic and anoxic conditions: Study of chromium speciation. J. Hazard. Mater. 2015, 283, 672-679. [CrossRef] [PubMed]

6. Kokkinos, E.; Proskynitopoulou, V.; Zouboulis, A. Chromium and energy recovery from tannery wastewater treatment waste: Investigation of major mechanisms in the framework of circular economy. J. Environ. Chem. Eng. 2019, 7, 103307. [CrossRef]

7. Kokkinos, E.; Zouboulis, A. Hydrometallurgical recovery of $\mathrm{Cr}(\mathrm{III})$ from tannery waste: Optimization and selectivity investigation. Water 2020, 12, 719. [CrossRef]

8. Mao, L.; Deng, N.; Liu, L.; Cui, H.; Zhang, W. Inhibition of $\mathrm{Cr}(\mathrm{III})$ oxidation during thermal treatment of simulated tannery sludge: The role of phosphate. Chem. Eng. J. 2016, 294, 1-8. [CrossRef]

9. Peng, H.; Leng, Y.; Guo, J. Electrochemical removal of chromium (VI) from wastewater. Appl. Sci. 2019, 9, 1156. [CrossRef]

10. Barrera-Díaz, C.E.; Lugo-Lugo, V.; Bilyeu, B. A review of chemical, electrochemical and biological methods for aqueous Cr(VI) reduction. J. Hazard. Mater. 2012, 223-224, 1-12. [CrossRef]

11. Patterson, R.R.; Fendorf, S.; Fendorf, M. Reduction of hexavalent chromium by amorphous iron sulfide. Environ. Sci. Technol. 1997, 31, 2039-2044. [CrossRef]

12. Sedlak, D.L.; Chan, P.G. Reduction of hexavalent chromium by ferrous iron. Geochim. Cosmochim. Acta 1997, 61, 2185-2192. [CrossRef]

13. Srinath, T.; Verma, T.; Ramteke, P.W.; Garg, S.K. Chromium (VI) biosorption and bioaccumulation by chromate resistant bacteria. Chemosphere 2002, 48, 427-435. [CrossRef]

14. Sivakumar, D. Biosorption of hexavalent chromium in a tannery industry wastewater using fungi species. Glob. J. Environ. Sci. Manag. 2016, 2, 105-124.

15. Arroyo, M.G.; Pérez-Herranz, V.; Montañés, M.T.; García-Antón, J.; Guiñón, J.L. Effect of pH and chloride concentration on the removal of hexavalent chromium in a batch electrocoagulation reactor. J. Hazard. Mater. 2009, 169, 1127-1133. [CrossRef]

16. Zongo, I.; Leclerc, J.P.; Maïga, H.A.; Wéthé, J.; Lapicque, F. Removal of hexavalent chromium from industrial wastewater by electrocoagulation: A comprehensive comparison of aluminium and iron electrodes. Sep. Purif. Technol. 2009, 66, 159-166. [CrossRef]

17. Chaudhary, A.J.; Goswami, N.C.; Grimes, S.M. Electrolytic removal of hexavalent chromium from aqueous solutions. J. Chem. Technol. Biotechnol. 2003, 78, 833-877. [CrossRef] 
18. Golub, D.; Oren, Y. Removal of chromium from aqueous solutions by treatment with porous carbon electrodes: Electrochemical principles. J. Appl. Electrochem. 1989, 19, 311-316. [CrossRef]

19. Abda, M.; Gavra, Z.; Oren, Y. Removal of chromium from aqueous solutions by treatment with fibrous carbon electrodes: Column effects. J. Appl. Electrochem. 1991, 21, 734-739. [CrossRef]

20. Rodriguez-Valadez, F.; Ortiz-Éxiga, C.; Ibanez, J.G.; Ordaz, A.A.; Gutierrez-Granados, S. Electroreduction of Cr(VI) to Cr(III) on reticulated vitreous carbon electrodes in a parallel-plate reactor with recirculation. Environ. Sci. Technol. 2005, 39, 1875-1879. [CrossRef]

21. Velasco, G.; Gutiérrez-Granados, S.; Ponce de León, C.; Alatorre, A.; Walsh, F.C.; Rodríguez-Torres, I. The electrochemical reduction of $\mathrm{Cr}(\mathrm{VI})$ ions in acid solution at titanium and graphite electrodes. J. Environ. Chem. Eng. 2016, 4, 3610-3617. [CrossRef]

22. Friedrich, J.M.; Ponce-de-León, C.; Reade, G.W.; Walsh, F.C. Reticulated vitreous carbon as an electrode material. J. Electroanal. Chem. 2004, 561, 203-217. [CrossRef]

23. Njau, K.N.; Janssen, L.J.J. Electrochemical reduction of chromate ions from dilute artificial solutions in a GBC-reactor. J. Appl. Electrochem. 1999, 29, 411-419. [CrossRef]

24. Joint Center for Powder Diffraction Studies (JCPDS). Powder Diffraction File; International Centre for Diffraction Data: Newtown Square, PA, USA, 2004.

25. Apha; Water Environment Federation; American Water Works Association. Standard Methods for the Examination of Water and Wastewater (Part 4000-6000); Water Environment Federation: Alexandria, VA, USA, 1999; ISBN 9780875532356.

26. USEPA. Method 7196A for Chromium Hexavalent (Colorimetric); USEPA: Washington, DC, USA, 1992.

27. European Standard 13137. In Chemical Analyses_Determination of Total Organic Carbon (TOC) in Waste, Sludges and Sediments; EN 2004; European Committee for Standardization: Brussels, Belgium, 2004.

28. Touni, A.; Papaderakis, A.; Karfaridis, D.; Banti, A.; Mintsouli, I.; Lambropoulou, D.; Sotiropoulos, S. Oxygen evolution at $\mathrm{IrO}_{2}$-modified Ti anodes prepared by a simple galvanic deposition method. J. Electroanal. Chem. 2019, 855, 113485. [CrossRef]

29. Apte, A.D.; Tare, V.; Bose, P. Extent of oxidation of $\mathrm{Cr}(\mathrm{III})$ to $\mathrm{Cr}(\mathrm{VI})$ under various conditions pertaining to natural environment. J. Hazard. Mater. 2006, 128, 164-174. [CrossRef]

30. Faris, N.; Ram, R.; Chen, M.; Tardio, J.; Pownceby, M.I.; Jones, L.A.; McMaster, S.; Webster, N.A.S.; Bhargava, S. The effect of thermal pre-treatment on the dissolution of chalcopyrite $\left(\mathrm{CuFeS}_{2}\right)$ in sulfuric acid media. Hydrometallurgy 2017, 169, 68-78. [CrossRef]

31. Verbinnen, B.; Billen, P.; van Coninckxloo, M.; Vandecasteele, C. Heating temperature dependence of Cr(III) oxidation in the presence of alkali and alkaline earth salts and subsequent $\mathrm{Cr}(\mathrm{VI})$ leaching behavior. Environ. Sci. Technol. 2013, 47, 5858-5863. [CrossRef]

32. Mao, L.; Gao, B.; Deng, N.; Zhai, J.; Zhao, Y.; Li, Q.; Cui, H. The role of temperature on Cr(VI) formation and reduction during heating of chromium-containing sludge in the presence of CaO. Chemosphere 2015, 138, 197-204. [CrossRef]

33. Soltani, F.; Abdollahy, M.; Petersen, J.; Ram, R.; Javad Koleini, S.M.; Moradkhani, D. Leaching and recovery of phosphate and rare earth elements from an iron-rich fluorapatite concentrate: Part II: Selective leaching of calcium and phosphate and acid baking of the residue. Hydrometallurgy 2019, 184, 29-38. [CrossRef]

34. Lide, D.R. CRC Handbook of Chemistry and Physics; CRC Press Taylor \& Francis: Boca Raton, FL, USA, 2005.

35. Brito, F.; Ascanio, J.; Mateo, S.; Hernández, C.; Araujo, L.; Gili, P.; Martín-Zarza, P.; Domínguez, S.; Mederos, A. Equilibria of chromate(VI) species in acid medium and ab initio studies of these species. Polyhedron 1997, 16, 3835-3846. [CrossRef]

36. Roberts, E.P.L.; Yu, H. Chromium removal using a porous carbon felt cathode. J. Appl. Electrochem. 2002, 32, 1091-1099. [CrossRef]

37. Kachoosangi, R.T.; Compton, R.G. Voltammetric determination of Chromium(VI) using a gold film modified carbon composite electrode. Sens. Actuators B Chem. 2013, 178, 555-562. [CrossRef]

38. Sun, Z.; Chai, L.; Shu, Y.; Li, Q.; Liu, M.; Qiu, D. Chemical bond between chloride ions and surface carboxyl groups on activated carbon. Colloids Surf. Physicochem. Eng. Asp. 2017, 530, 53-59. [CrossRef]

39. Bard, A.J.; Faulkner, L.R. Methods involving forced convection-hydrodynamic methods. In Electrochemical Methods: Fundamentals and Applications, 2nd ed.; John Wiley \& Sons, Inc.: New York, NY, USA, 2001; p. 341. 